\title{
THE INFLUENCE OF ORGANIZATIONAL CULTURE AND WORK ENVIRONMENT ON EMPLOYEE LOYALTY WHICH AN IMPACT ON THE PERFORMANCE OF EMPLOYEES OF PT PATRIA MARITIM PERKASA (PMP) BATAM
}

\author{
Andhi Kusuma ${ }^{1}$, Indrayani ${ }^{2}$, Bambang Satriawan ${ }^{3}$, Chablullah Wibisono ${ }^{4}$ \\ Faculty of Economics, Department of Management, University of Batam \\ E-mail: ${ }^{1)}$ andhikusuma165@gmail.com
}

\begin{abstract}
The cause of this research is to understand the affect of organizational culture and work environment towards the loyalty of personnel in addition to their impact at the performance of employees of PT. Patria Maritim Perkasa Batam. approach of statistics collection on this observe is a questionnaire, remark, documentation. strategies of descriptive and quantitative techniques with course evaluation that may be used to measure the affect of organizational culture and work surroundings towards the loyalty of employees as well as their effect at the overall performance of employees of PT Patria Maritim Perkasa Batam. based totally on a take a look at of the free variable F (organizational culture, work environment) mutually have a fantastic and huge impact against the variable is certain ( the loyalty of personnel and employee performance).
\end{abstract}

Keywords: Organizational Culture, Work environment, Employee Loyalty and Employee Performance

\section{INTRODUCTION}

PT Patria Maritim Perkasa Batam established at Batam in 2005 ( the previous name is Perkasa Melati and acquisition by Astra International in 2012) at Jalan Sei Binti No.20, Sungai Lekop, Sagulung, Kota Batam, Kepulauan Riau. This company is subsidiary of United Tractors and Astra International group. The business segment is Ship Design, Building, \& Repair that have the vision Provide the world class ship design and technical solution to customers and New Building of HighTech Ship. As Astra Group member, PT Patria Maritim Perkasa Have commitment for implement Good Coorporate Governance (GCG) as our culture of Company.

PT Patria Maritim Perkasa Batam always to improve and maintain the quality of human resources, provide training and provide development programs for employees to increase their potential or abilities to that will support performance in the company. In addition, the company is committed to implementing a work culture based on Quality, Cost, Delivery, Safety ( QCDS) is expected to compete in the international World.

Organizational Culture is very influential in the progress of the company to growth and sustain. PT Patria Maritim Perkasa have a organizational culture that is PATRIA ( Pro-active, Agile, Team Player, Resilient, Innovative, Accountable). Organizational Culture must be implement as personal habbits to increase employee performance for support the company Goal.

By creating a conducive work environment, there will be very wide opportunities for the development of the learning process or learning from each other at work. They will be more enthusiastic in solving all problems that arise, both from inside and outside the organization. herefore, a good organizational culture and a conducive work environment tied to work commitments will lead to job loyalty and can improve employee performance. Literature review for this journal: 
THE INFLUENCE OF ORGANIZATIONAL CULTURE AND WORK ENVIRONMENT ON EMPLOYEE LOYALTY WHICH AN IMPACT ON THE PERFORMANCE OF EMPLOYEES OF PT PATRIA MARITIM PERKASA (PMP) BATAM

DOI: https://doi.org/10.54443/ijerlas.v2i1.145

a. Organizational Culture

Robbins and Coulter (2010) Organizational culture is a set of values, principles, traditions and ways of working that are shared and influence the behavior and actions of organizational members. The indicators (Robbins, Judge 2016) include innovation and risk taking, team orientation, result orientation, leader behavior, prioritizing the company's mission.

b. Work Environment

Work environment According to Basuki and Susilowati in Arta (2013) the work environment is anything that is in the environment that can directly or indirectly affect a person or group of people in carrying out their activities. The indicators in this study according to (Sedarmayanti 2001) are lighting, work relations, comfort, availability of work facilities, noise.

c. Employee Loyality

Sudiman (2003) job loyalty means the willingness of employees with all the abilities, skills, thoughts and time to participate in achieving company goals and keep company secrets and not take actions that are detrimental to the company as long as that person is still an employee. The indicators of loyalty in this study according to Runtu (2014), namely: loyalty, persistence, regulation, being active in the organization.

d. Employee Performance

Payaman Simanjuntak in Rivai (2015) performance is the level of achievement of results for the implementation of certain tasks. Meanwhile, Rivai, Ramly et al (2015) stated that performance is a function of motivation and ability. To complete a person's assignments and work, a certain degree of willingness and ability should be obtained. Employee performance indicators according to Robbins (2002) are quality, quantity, timeliness and the need for supervision.

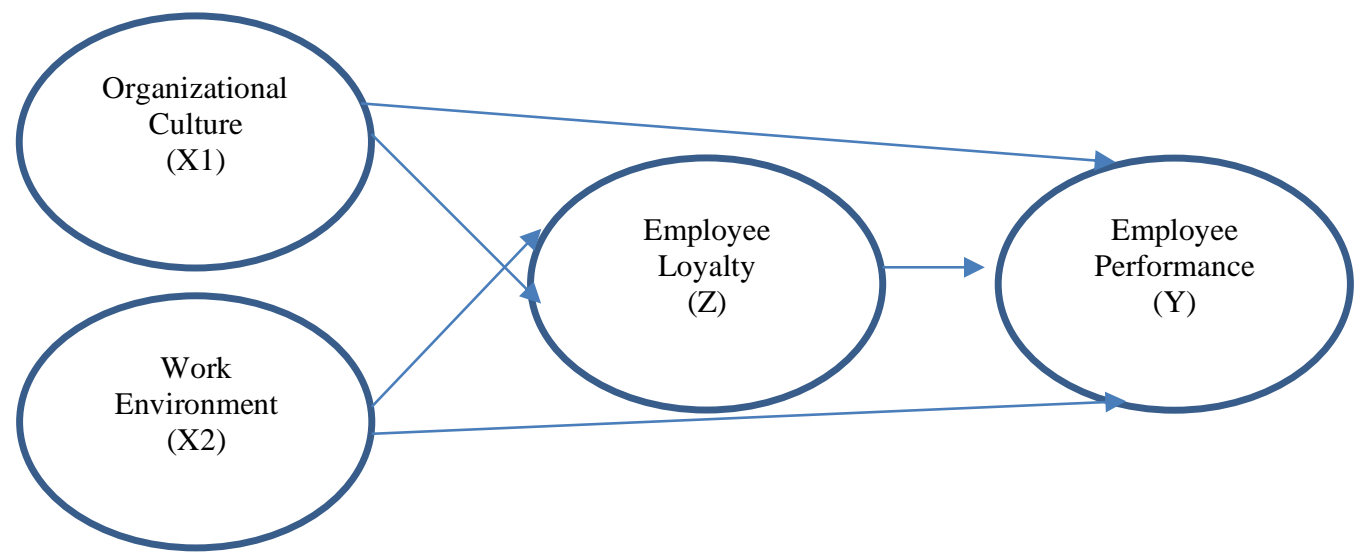

Picture 1. Conceptual Framework

In this conceptual framework, there is also a direct and indirect effect of the independent variables on the intermediate and dependent variables. The direct influence shown from this conceptual framework is the influence of work culture, work environment on employee loyalty. Direct influence is also shown, namely the influence of organizational culture, work environment on employee performance. While the indirect influence is shown, namely the influence of 
organizational culture, work environment on employee performance through employee loyalty. And the direct effect of employee loyalty on employee performance.

\section{IMPLEMENTATION METHOD}

This research is a descriptive study with quantitative approach. Descriptive research is an exposure aimed to provide a description of a problem, situation or event as it is to reveal facts.

a. Place of the Research

The location of this research was employee work at PT Patria Maritim Perkasa Batam only.

\section{b. Population and Sample}

The target population in journal were employees of PT Patria Maritim Perkasa Batam only. A sample 87 people were selected. To fulfill scientific writing, this study uses an analytical model such as the following:

\section{- Path Analysis}

Path analysis is an analysis used to trace the relationship between variables in the model created. This analysis tool can explain the direct and indirect effects of a set of exogenous variable to endogenous variable.

The formula used in the path analysis model uses the following equation:

$\mathrm{Z}=\mathrm{PZ} \mathrm{X} 1+\mathrm{PZ} \mathrm{X} 2+\mathrm{C} 1$ (Structural Equation 1$)$

$\mathrm{Y}=\mathrm{PY} \mathrm{X} 1+\mathrm{PY} \mathrm{X} 2+\mathrm{C} 2$ (Structural Equation 2)

$\mathrm{Z}=$ Dependent Variable (endogen)

$\mathrm{X} 1$ = Independent Variable (eksogen)

$\mathrm{X} 2$ = Independent Variable (eksogen)

$\mathrm{Y}=$ Dependent Variable (endogen)

$\epsilon 1, \epsilon 2=$ Error

\section{c. Techniques for Collecting Data and Analyzing Data}

The data collection was done in several ways, namely:

a. Observing directly to the research location. This observation was carried out to obtain an overview of the workplace atmosphere, work processes and other things needed.

b. Disseminating questionnaires to the respondents. The questionnaire used in this study contained employee perceptions relating to organizational Culture, Work environment, employee loyalty, and employee performance

\section{RESULTS AND DISCUSSION}

\section{a. Result}

Table 1. Influence of organizational Culture(X1), Work environment (X2) on Employee Loyalty $(Z)$

\begin{tabular}{|l|l|l|l|l|l|}
\hline \multirow{2}{*}{ Dependent Variable } & \multirow{2}{*}{ Independent Variable } & \multicolumn{2}{|l|}{ Summary Model } & \multicolumn{2}{l|}{$\begin{array}{l}\text { Analysis of Variance } \\
\text { (Anova) }\end{array}$} \\
\cline { 4 - 7 } & & R & R Square & F & Sig \\
\hline \multirow{2}{*}{ Employee Loyalty (Z) } & Organizational Culture (X1) & 0.503 & 0.253 & 19156 & \multirow{2}{*}{0.0000} \\
\cline { 2 - 6 } & Work Environment (X2) & &
\end{tabular}


THE INFLUENCE OF ORGANIZATIONAL CULTURE AND WORK ENVIRONMENT ON EMPLOYEE LOYALTY WHICH AN IMPACT ON THE PERFORMANCE OF EMPLOYEES OF PT PATRIA MARITIM PERKASA (PMP) BATAM

DOI: https://doi.org/10.54443/ijerlas.v2i1.145

Seeing the influence of organizational culture, work environment in combination with employee loyalty at PT Patria Maritim Perkasa Batam. The research results can be described as follows:

1. The correlation coefficient $(\mathrm{R})$ is 0.503 . This shows that there is a strong relationship between organizational culture, work environment and employee loyalty at PTPatria Maritim Perkasa Batam.

2. The determinant coefficient ( $\mathrm{R}$ square) is 0.253 . This shows that the magnitude of the influence between the variables of organizational culture, work environment on employee loyalty by calculating the coefficient $(\mathrm{KD})$ with the formula:

$$
\begin{aligned}
& \mathrm{KD}=\mathrm{r}^{2} \times 100 \% \\
& \mathrm{KD}=0.253 \times 100 \% \\
& \mathrm{KD}=25.3 \%
\end{aligned}
$$

This figure shows that the effect of organizational culture, work environment on employee loyalty in combination is $25.3 \%$, while the remaining $74.7 \%$ is influenced by other factors or other variables outside of this model.

3. Value of $\mathrm{F}_{\text {count }}$ obtained is 19.156 , while $\mathrm{F}_{\text {table }}$ on the confident percentage $95 \%$ or margin error $(\alpha=0,05)$ will get the number 3.075. thus, value of $F_{\text {count }}<F_{\text {table }}$ or $19.156<3.075$. which means, the independent variable will influence simultaneously with the dependent variable. Based on this table, it can be concluded that the variable organizational culture (X1), work environment (X2) has a significant effect on employee loyalty (Z) at PT Patria Maritim Perkasa Batam.

\begin{tabular}{|c|c|c|c|c|c|}
\hline \multirow{2}{*}{ Dependent Variable } & \multirow{2}{*}{ Independent Variable } & \multicolumn{2}{|c|}{ Summary Model } & \multicolumn{2}{|c|}{$\begin{array}{l}\text { Analysis of Variance } \\
\text { (Anova) }\end{array}$} \\
\hline & & $\mathrm{R}$ & $\begin{array}{l}\mathrm{R} \\
\text { Square }\end{array}$ & $\mathrm{F}$ & Sig \\
\hline \multirow{3}{*}{$\begin{array}{l}\text { Employee } \\
\text { Performance (Y) }\end{array}$} & $\begin{array}{l}\text { Organizational Culture } \\
\text { (X1) }\end{array}$ & \multirow{3}{*}{0.734} & \multirow{3}{*}{0.539} & \multirow{3}{*}{43.677} & \multirow{3}{*}{0.0000} \\
\hline & Work Environment (X2) & & & & \\
\hline & Employee Loyalty (Z) & & & & \\
\hline
\end{tabular}

Table 2. Influence of organizational Culture(X1), Work environment (X2) Employee Loyalty (Z) on Employee Performance (Y)

Seeing the influence of organizational culture, work environment, and employee loyalty in combination with employee performance at PT Patria Maritim Perkasa Batam. The research results can be described as follows:

1. The correlation coefficient $(\mathrm{R})$ is 0.734 . This shows that there is a strong relationship between organizational culture, work environment and employee loyalty on employee Performance at PT Patria Maritim Perkasa Batam.

2. The determinant coefficient ( $\mathrm{R}$ square) is 0.539 . This shows that the magnitude of the influence between the variables of organizational culture, work environment, and employee loyalty on employee performance by calculating the coefficient (KD) with the formula:

$$
\begin{aligned}
& \mathrm{KD}=\mathrm{r}^{2} \times 100 \% \\
& \mathrm{KD}=0.539 \times 100 \% \\
& \mathrm{KD}=53,9 \%
\end{aligned}
$$


This figure shows that the effect of organizational culture, work environment, and employee loyalty on employee performance in combination is $53,9 \%$, while the remaining $46,1 \%$ is influenced by other factors or other variables outside of this model.

3. Value of $\mathrm{F}_{\text {count }}$ obtained is 43,677 , while $\mathrm{F}_{\text {table }}$ on the confident percentage $95 \%$ or margin error $(\alpha=0,05)$ will get the number 3.075. thus, value of $F_{\text {count }}<F_{\text {table }}$ or $43.677<3.075$. which means, the independent variable will influence simultaneously with the dependent variable. Based on this table, it can be concluded that the variable organizational culture (X1), work environment (X2) has a significant effect on employee loyalty (Z) at PT Patria Maritim Perkasa Batam.

\section{b. Discussion}

\section{The Influence of Organizational Culture on Employee Loyalty}

In accordance with the results of testing the hypothesis, it can be explained that organizational culture has a direct and significant effect on employee loyalty. This means that the better the implementation of the organizational culture adopted by each employee, the higher the employee loyalty attitude in the company PT Patria Maritim Perkasa Batam.

\section{The Influence of Work Environment on Employee Loyalty}

In accordance with the results of testing the hypothesis, it can be explained that the work environment has a direct and significant effect on employee loyalty. This means that the better the work environment felt by each employee, the higher the attitude of employee loyalty in PT Patria Maritim Perkasa Batam.

\section{The Influence of Organizational Culture on Employee Loyalty}

The influence of organizational culture can create situations that can encourage employees to improve their performance. Because with the existence of a good and directed organizational culture, it can carry out work in sequence with maximum results. Without an organizational culture that is applied to an organization or company, it will be difficult for the organization or company to achieve the desired goals. Organizational Culture must be personal habbits.

\section{The Influence of Work Environment on Employee Performance}

In accordance with the results of testing the hypothesis, it can be explained that the work environment has a direct and significant effect on employee performance. This means that the better the work environment perceived by each employee, the higher the employee's performance level. Conversely, an inadequate work environment will reduce the performance of employees in PT Patria Maritim Perkasa Batam.

\section{The Influence of Employee Loyalty on Employee Performance}

In accordance with the results of testing the hypothesis, it can be explained that employee loyalty has a direct and significant effect on employee performance. This means that the better employee loyalty, the higher the level of employee performance in PT Patria Maritim Perkasa Batam.

6. The Influence of Organizational Culture on Employee Performance through Employee Loyalty

Based on the results of hypothesis testing in this study, it was found that the direct influence of organizational culture on employee performance was 0.257 . While the indirect effect of organizational culture through employee loyalty on employee performance is 0.040, while the total effect of organizational culture on employee performance is the direct 
influence plus the indirect effect, namely: $0.257+0.040=0.297$. Because the direct relationship coefficient is greater than the indirect relationship coefficient, it can be said that the actual relationship is direct, which means that the stronger the organizational culture that is built or developed by the leader is able to bind and influence the behavior of individual organizational actors (owner, management, employees), professionalism in work, prioritizing the company's vision and mission, team orientation, organizational culture as a learning process and with an organizational culture that is flexible and responsive to the dynamics of the internal and external environment of the organization without going through employee loyalty being sufficiently able to influence employee performance improvement at PT Patria Maritim Perkasa Batam.

7. The Influence of Work Environment on Employee Performance through Employee Loyalty

Based on the results of hypothesis testing in this study, it is known that the direct effect of the work environment on employee loyalty is 0.295 . While the indirect effect of the work environment through employee loyalty on employee performance is 0.046 , while the total influence given by organizational culture on employee performance is the direct effect plus the indirect effect, namely: $0.295+0.046=0.341$. Because the direct relationship coefficient is greater than the indirect relationship coefficient, it can be said that the actual relationship is direct, which means that the stronger the work environment is felt or obtained by employees, be it elements of leadership, co-workers, compensation, work mechanisms that take place in organization as well as external influences outside of the influence of the company organization is quite good for employees, so without going through the loyalty of an employee it can improve employee performance at PT Patria Maritim Perkasa Batam.

\section{CONCLUSION}

Based on results of data analysis, and from the questionnaire, organizational Culture and Work Environment influences employee Loyalty, and Organizational culture and Work environment have direct Impact on Employee Performance, Employee Loyalty have indirect effect on employee Performance.

\section{REFERENCES}

Adi, Arta Kusuma. 2013. Pengaruh Motivasi dan LIngkungan Kerja terhadap Kinerja Karyawan Hotel Muria Semarang. Jurnal Manajemen

Agus Tunggal Saputra dkk, 2016. Pengaruh Kepuasan Dan Loyalitas Karyawan terhadap Kinerja Karyawan PT. Sun Motor Cabang Negara. Jurnal Manajemen

Ardana, I Komang dkk. 2012. Manajemen Sumber Daya Manusia. Yogyakarta: Graha Ilmu H. Koesmono, Teman. 2005.

Ilham, R. N., Sadalia, I., Irawati, N., \& Sinta, I. (2022). Risk And Return Model of Digital Cryptocurrency Asset Investment In Indonesia. Al Qalam: Jurnal Ilmiah Keagamaan dan Kemasyarakatan, 16(1), 357-376. 
Pengaruh Budaya Organisasi Terhadap Motivasi Dan Kepuasan Kerja Serta Kinerja Karyawan Pada Sub Sektor Industri Pengolahan Kayu Skala Menengah Di Jawa Timur. Jurnal Ekonomi Manajemen Hertiani, Surya, bagus. 2014.

Pengaruh lingkungan kerja, budaya organisasi dan Kepemimpinan terhadap kinerja karyawan koran pada PT. Tempo Jateng dan D.I Yogyakarta. Jurnal Manajemen

Karisma. Bara G. 2013. Pengaruh budaya organisasi, lingkungan kerja terhdap kinerja karyawan koperasi serba usaha setya usaha di kabupaten jepara. Jurnal Manajemen

Khaddafi, M., \& Apriani, N. (2021). Analisis Kinerja Keuangan untuk Mengukur Tingkat Kesehatan Koperasi Simpan Pinjam Syariah di Kota Lhokseumawe. Jurnal EMT KITA, $5(1), 66-82$.

Mariam, Rani. 2009. Pengaruh gaya kepemimpinan dan budaya organisasi terhadap kinerja karyawan melalui kepuasan kerja karyawan sebagai variabel intervening. Studi pada kantor pusat PT. Asuransi Jasa Indonesia (Persero).

Tesi Permansari, Ragil. 2013. Pengaruh Motivasi dan lingkungan Kerja terhadap Kinerja Karyawan PT. Anugrah Raharjo Semarang. Jurnal Manajemen Pima, nela, Bambang dkk. 2014.

Santoso, J. T., Ginantra, N. L. W. S. R., Arifin, M., Riinawati, R., Sudrajat, D., \& Rahim, R. (2021). Comparison of Classification Data Mining C4. 5 and Naïve Bayes Algorithms of EDM Dataset.

Studi Pengaruh Lingkungan Kerja Terhadap Kinerja Karyawan Kantor Pelayanan Pajak Pratama Malang Utara. Jurnal Administrasi Bisnis. Rivai, Veithzal, Ramly dkk. 2015.

Mahdi, M., \& Khaddafi, M. (2020). The Influence of Gross Profit Margin, Operating Profit Margin and Net Profit Margin on the Stock Price of Consumer Good Industry in the Indonesia Stock Exchange on 2012-2014. International Journal of Business, Economics, and Social Development, 1(3), 153-163.

Manajemen Sumber Daya Manusia Untuk Perusahaan. Edisi Ketiga. Cetakan Ketuju. PT. Raja Grafindo Persada: Jakarta

Robbins, S.P. 2002. Prinsip-Prinsip Perilaku Organisasi. Jakarta: Erlangga

Robbins, S.P., M. Coulter. 2010. Management , Edisi Kesepuluh, Jilid 2. Jakarta:Penerbit Erlangga Robbins, S. Judge. 2016.

Rusydi, R., Adnan, A., Sutan, S., \& Bachri, N. (2021). THE INFLUENCE OF ENVIRONMENT, E-WOM, AND FACILITIES ON TOURIST DECISIONS TO VISIT SAWUEK RIVER, NORTH ACEH, INDONESIA. International Journal of Educational Review, Law And Social Sciences (IJERLAS), 1(2), 207-214.

Perilaku Organisasi. Edisi 16. Jakarta: Salemba Empat Runtu, Julius, (26 Februari 2014).

Indikator loyalitas karyawan (bahan diskusi v MSDM II . (online) Diakses dari http://juliusruntu.blogspot.com/2014/02/indikator-loyalitas-karyawan-bahan.html Diakses pada tanggal 25 juli 2016. Sahal Tastariwal. Muhlis dkk. 2013.

Studi analisis pengaruh insentif, budaya kerja, lingkungan kerja terhadap loyalitas serta dampaknya terhadap kepuasan kerja karyawan hotel di kota banda aceh. Jurnal Manajemen. Sedarmayanti. 2001.

Sumber Daya Manusia dan Produktivitas kerja. Bandung: Mandar maju 
THE INFLUENCE OF ORGANIZATIONAL CULTURE AND WORK ENVIRONMENT ON EMPLOYEE LOYALTY WHICH AN IMPACT ON THE PERFORMANCE OF EMPLOYEES OF PT PATRIA MARITIM PERKASA (PMP) BATAM

DOI: https://doi.org/10.54443/ijerlas.v2i1.145 